Leibniz amongst the worthies to whom the credit of improvements in the steam-engine is given. The one common feature that runs through the many different types of steam-engine is the piston working within a cylinder. No engine before Papin's time was adapted for any useful purpose except for raising water, and none had a piston in a cylinder. No engine since Papin's time of the thousand varied types has been devoid of this feature. But the very feature which Papin introduced, and on the introduction of which his claim to be called the inventor of the steam-engine has been founded, was, as we now know, the suggestion of another mind. We owe the application of the piston-principle in the steam-engine, not to Papin, but to Leibniz.

\section{CHEMISTRY OF THE FARM}

The Chemistry of the Farm. By R. Warington, F.C.S. Pp. xiii. and 128. (London: Bradbury, Agnew, and Co., I881.)

$\mathrm{T}^{\mathrm{s}}$ $\mathrm{HE}$ chapters of this little handbook appeared originally in detached portions in the Agricultural Gazette. They have been revised, and are now issued in a convenient and compact form. A well-ordered manual of agricultural chemistry, clearly written and perfectly abreast of recent advances in the sciences underlying the farming art, has long been wanted. So far as the limits of its size and scope allow, Mr. Warington's volume fulfils our expectations. It is a satisfaction which is seldom afforded us to read a book on agricultural chemistry written by a true chemist trained in laboratory work and versed in the progress made through English and foreign researches. The applications of chemistry to agriculture are manifold, and cannot be grasped by chemists who do not combine with their chemistry a competent knowledge of vegetable and animal physiology and of mineralogy. Yet to learn or to teach the Chemistry of the Farm without a knowledge even of the foundations of chemical science is commonly attempted, though it can never succeed in any true sense. And we quite agree with Mr. Warington that a wider range of scientific knowledge than this is needed even for the student of agricultural chemistry-much more then for the teacher. To talk about this applied science to persons without previous scientific knowledge, and to look for satisfactory results, is to expect a plant unfortunately destitute of roots to blossom and bear fruit.

We think then that Mr. Warington's handbook is valuable on account not only of the knowledge with which its subject is handled, but also on account of the spirit with which that subject is approached. That a new work on agricultural chemistry was sorely needed does not admit of question. In France and in Germany the educational literature of this subject includes many excellent works which have no English counterparts. Johnston's treatise, full as it is of valuable observations, is too thoroughly out of date in method as well as in matter to admit of satisfactory revision; much the same judgment must be passed on Anderson's "Agricultural Chemistry," now twenty years old and out of print. Even if Georges Ville's work on Manures included (which it is far from doing) anything like the whole domain of the Chemistry of the Farm, it is about as unsafe and misleading a book as could be put into the hands of a student. Mr. Warington has given us, in fact, not all we want, but a good bit of it. He has used, and that judiciously, both German and English text-books, researches, and memoirs, and has put the main facts they enounce into a neat form, so as to be "understanded of the people." The two capital text-books of Emil Wolff have been laid under contribution by Mr. Warington; while the chief results of some of the matchless Rothamsted Memoirs by Lawes and Gilbert have been skilfully introduced into his pages. Of the contents of these it is now perhaps time to say a few words. In five chapters the growth, the food, the nutrition, and the products of farm crops are discussed; in another five, animal growth, food, nutrition, and products. Of the diverse origins and properties of soils but little is said; as to the utilisation of urban sewage, nothing. And we should have been glad to have found fuller accounts of many subjects which are but lightly touched upon in these pages. But the difficulty of treating so vast and complex a subject intelligibly in so few pages makes us surprised, not that some things are omitted from, but that such a large number of things are included in, this little book. Some facts and figures which the author would doubtless have liked to introduce have been kept out of his pages by the absolute necessity of finding room for numbers and arguments of primary importance. For instance, it would have been unwise to have curtailed the space bestowed upon the "Digestibility of Foods" and the "Albuminoid Ratio."

In reading through this handbook carefully we have been unable to discover more than a very few statements which we cannot completely endorse ; in fact the majority of such alterations as we would suggest would be of form rather than of substance. We cannot, however, refrain from expressing our regret that the percentages of albuminoids in potatoes and roots as given in the table on p. 72 should be the old erroneous figures condemned on the very next page as greatly in excess of the truth. Mr. Warington has however so thoroughly recognised the importance of the discrimination between albuminoid and non-albuminoid nitrogen that we must attribute the inclusion of the incorrect figures in his tables to the difficulty of constructing a complete series of analyses comparable with one another in this particular of the percentage of true albuminoids.

A. H. CHURCH

\section{OUR BOOK SHELF}

A Handbook of the Vertebrate Fauna of Yorkshire. Being a Catalogue of British Mammals, Birds, Reptiles, Amphibians, and Fishes, showing what species are or have within historical periods been found in the County. By Wm. Eagle Clarke and Wm. Denison Roebuck. (London: Reeve and Co., r88I.)

THIs little volume is dedicated to the President-Elect of the British Association, and most seasonably makes its appearance on the eve of the meeting of that Association in the city and county of its origin, when it will celebrate the completion of the first fifty years of its existence. Its object is the enumeration of those animals with a vertebral column which either are or have been found in Yorkshire, and the careful definition of their faunistic position and geographical distribution within the county. It would appear that there has never been a list of the mammals, birds, or fishes of the county of York published, and in this respect it presents a striking contrast with its neighbouring counties of Norfolk, Northumberland, and 